\title{
Conditioning Thermal Stability and Dose Effects of Commercially Available Phytase Preparations on Performance and Tibia Mineralization of Young Broiler Chickens
}

Victoria B. Homan

Follow this and additional works at: https://researchrepository.wvu.edu/etd

\section{Recommended Citation}

Homan, Victoria B., "Conditioning Thermal Stability and Dose Effects of Commercially Available Phytase Preparations on Performance and Tibia Mineralization of Young Broiler Chickens" (2016). Graduate Theses, Dissertations, and Problem Reports. 5817.

https://researchrepository.wvu.edu/etd/5817

This Thesis is protected by copyright and/or related rights. It has been brought to you by the The Research Repository @WVU with permission from the rights-holder(s). You are free to use this Thesis in any way that is permitted by the copyright and related rights legislation that applies to your use. For other uses you must obtain permission from the rights-holder(s) directly, unless additional rights are indicated by a Creative Commons license in the record and/ or on the work itself. This Thesis has been accepted for inclusion in WVU Graduate Theses, Dissertations, and Problem Reports collection by an authorized administrator of The Research Repository @ WVU. For more information, please contact researchrepository@mail.wvu.edu. 
Conditioning Thermal Stability and Dose Effects of Commercially Available Phytase Preparations on Performance and Tibia Mineralization of Young Broiler Chickens

\author{
Victoria B. Homan
}

Thesis submitted to the Davis College of Agriculture and Design at West Virginia University in partial fulfillment of the requirements for the degree of

Master of Science in

Nutrition and Food Science

Joseph Moritz, Ph.D., Chair

Jacek Jaczynski, Ph.D.

Janet Tou, Ph.D.

Department of Animal and Nutritional Sciences

Morgantown, West Virginia

2016

Keywords: Phytase, broiler, conditioning temperature, transgenic corn

Copyright 2016 Homan 


\title{
ABSTRACT \\ Conditioning Thermal Stability and Dose Effects of Commercially Available Phytase Preparations on Performance and Tibia Mineralization of Young Broiler Chickens
}

\author{
Victoria Homan
}

Phytases have become a vital part of broiler diets due to their ability to decrease feed cost and potential environmental pollution caused by the use of excessive phosphorus. The objective of the first study was to compare the effects of various inclusions of a Transgenic Phytase Corn (TPC) to a Granulated Bacteria Phytase (GBP) on 21-d broiler performance and tibia mineralization. Treatments varied in non-phytate phosphorus (Negative control $(\mathrm{NC})=0.2$, positive control $(\mathrm{PC})=0.4,0.3$, and 0.35), phytase product (TPC or GBP), and phytase dose (500-3000 FTU/kg). A 2x2 factorial analysis was performed with the main effects phytase activity and phytase product. The inclusion of granulated bacterial phytase resulted in increased broiler performance and tibia mineralization compared to the inclusion of transgenic phytase corn. This may be attributed to variations in dispersion of enzyme within the diet or the general efficacy of the expressed enzyme. The inclusion of a commercial phytase at 3,000 FTU/kg increased broiler performance and tibia mineralization compared to inclusion at $500 \mathrm{FTU} / \mathrm{kg}$. These results may be due to a greater reduction of phytate, alleviating anti-nutrient effects.

The objective of the second study was to evaluate the effects three commercial 6-phytase products with a phosphorus deficient diet subjected to increased steam conditioning temperatures on broiler performance and tibia mineralization. Treatments included a negative control, and a negative control with the addition of a Buttiauxella phytase expressed in Trichoderma reesei (B Trich), an E. coli phytase expressed in Pichia pastoris (E Pichia), or an E. coli phytase expressed in Trichoderma reesei (E Trich), steam conditioned at 82,88 , or $93^{\circ} \mathrm{C}$, for a total of twelve treatments. Broiler performance and tibia mineralization were analyzed using a 4 × 3 factorial with the main effects of product and conditioning temperature. The commercial phytase products demonstrated differences in supporting the phosphorus requirement in broilers. Increasing conditioning temperatures had a detrimental effect on broiler performance and tibia mineralization. The increased conditioning temperatures may have decreased nutrient availability, denatured phytase products, or both of these events may have influenced the results. 


\section{TABLE OF CONTENTS}

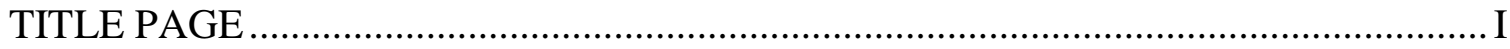

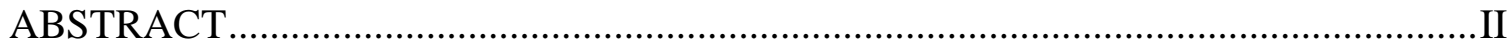

TABLE OF CONTENTS …………………………….......................................... III

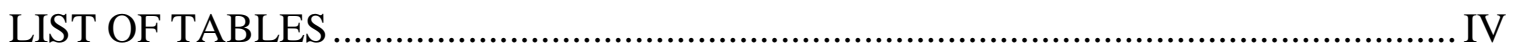

\section{CHAPTER ONE}

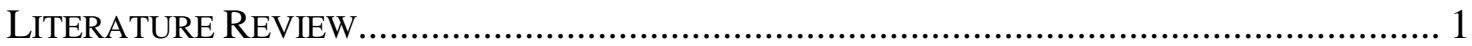

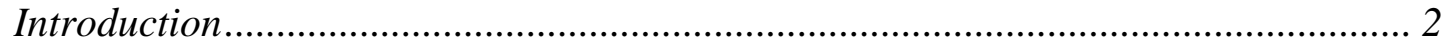

Commercial Phytase Sources ......................................................................... 4

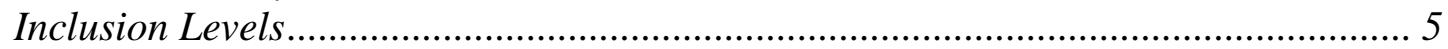

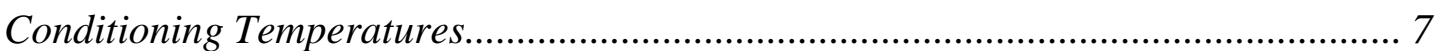

Conclusions and Future Research ………………….................................... 8

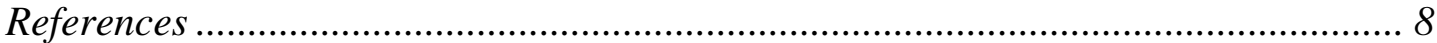

\section{CHAPTER TWO}

THE EFFECT OF VARYING LEVELS OF COMMERCIAL AND NOVEL PHYTASE PRODUCTS ON BROILER PERFORMANCE AND TIBIA MINERALIZATION ............................................................. 12

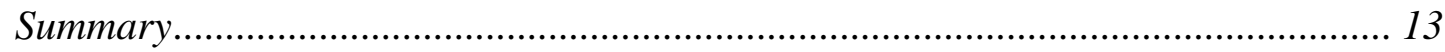

Description of the Problem …………………………………………………... 14

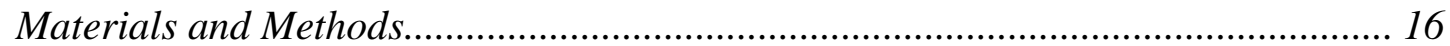

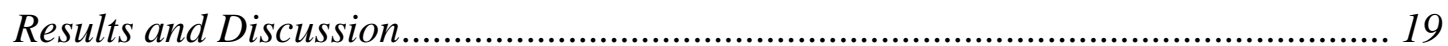

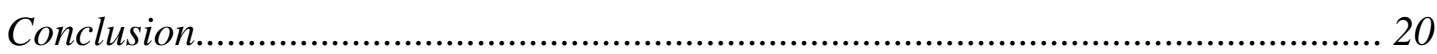

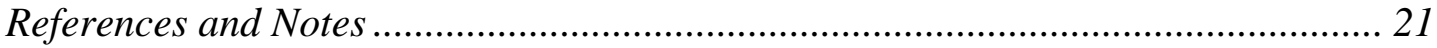

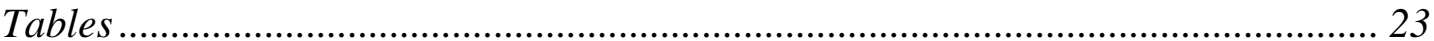

\section{CHAPTER THREE}

THE EFFECT OF DIETS VARYING IN COMMERCIAL PHYTASE PRODUCT SUBJECTED TO INCREASING STEAM CONDITIONING TEMPERATURE ON BROILER PERFORMANCE AND TIBIA MINERALIZATION

Summary.... 27

Description of the Problem 29

Materials and Methods. 31

Results and Discussion. 34

Conclusions 35

References and Notes. 36

Tables 38 


\section{LIST OF TABLES}

\section{CHAPTER TWO}

Table 1. Ingredients, calculated nutrient content, and analyzed nutrient content of diets provided to Hubbard x Cobb 500 broilers from 1-21 d of age. 23

Table 2. Statistical comparison of all dietary treatments as well as the factorial arrangement of treatments on $21 \mathrm{~d}$ Hubbard x Cobb straight-run broiler performance. 24

Table 3. Phosphorus equivalency values calculated from standard curve linear regression using Dicalcium Phosphorus. 25

\section{CHAPTER THREE}

Table 1. Diet formulation and calculated nutrient values 38

Table 2. Descriptive feed manufacture data of dietary treatments steam conditioned in a $0.31 \mathrm{x}$ $1.3 \mathrm{~m}$ conditioner for $10 \mathrm{~s}$ and extruded through a $4.7 \times 38 \mathrm{~mm}$ pellet die. 39

Table 3. Analyzed nutrient content of diets provided to Hubbard x Cobb 500 broilers from 1-20 d of age. 39

Table 4. Statistical comparison of all dietary treatments as well as the factorial arrangement of treatment on $20 \mathrm{~d}$ Hubbard x Cobb straight-run broiler performance. 40 


\section{CHAPTER 1}

\section{Literature Review}

Conditioning Thermal Stability and Dose Effects of Commercially Available Phytase Preparations on Performance and Tibia Mineralization of Young Broiler Chickens

V.B. Homan 


\section{Introduction}

Poultry receive the majority of their phosphorus in the form of phytate (myo-inositol hexakisphosphate, IP6). Phytate accounts for 60-70\% of phosphorus in typical corn and soybean based poultry diets (NRC, 1994). Phosphorus is essential for proper bone development and for the utilization of energy. Phytate is not easily digested, as it forms insoluble complexes with other nutrients. Poultry also lack the endogenous enzymes required to effectively dephosphorylate phytate, having the ability to only digest around $10 \%$ of the phytate provided to them (Adeola and Sands, 2003; Bedford and Schulze, 1998). As a result, phosphorus is excreted in manure, which can make its way into local water sources, where it has been implicated as having a detrimental environmental effect (Biehl et al., 1998). Sharpley (1999) found that increased phosphorus content in water increases eutrophication, which restricts water use for fisheries, recreation, industry, and drinking, due to the increased growth of undesirable algae. The uncontrolled algae growth is referred to as algal blooms, which not only contaminate drinking water, but also deplete the water of oxygen, killing aquatic life. Due to the low digestibility of phytate, excessive levels of phosphorus must be included in the diet, which increases both potential environmental pollution and feed costs.

As an alternative to increasing the inclusion of phosphorus, exogenous phytase may be added to diets. Exogenous phytase is added to most commercial broiler diets in order to improve nutrient availability, decrease costs, and reduce environmental pollution (Bedford, 2000; Dilger et al 2004). Exogenous phytase is able to make otherwise inaccessible phosphorus available to poultry by hydrolyzing the phytate molecule (Ravindran et al., 1995). Microbial phytases are classified based on the site of initial hydrolysis. A 6-phytase will dephosphorylate phytate in a sequential way, beginning with the phosphate group at position 6, whereas a 3-phytase would not begin hydrolyzing phytate 
until position 3 (Greiner et al., 2000). The full sequence of hydrolysis down to myo-inositol has yet to be determined (Maenz, 2001).

Exogenous phytase supplementation has been shown to improve broiler performance, indicated by increased weight gain, nutrient utilization, and tibia ash percentages (Gurbuz et al., 2008). Sebastian et al. (1996) found that the inclusion of exogenous phytase increased utilization of phosphorus (and therefore $\mathrm{Ca}, \mathrm{Zn}$, and $\mathrm{Cu}$ ) leading to increased bone mineralization, which can be measured by tibia ash percentage. However, many factors play a role on the effectiveness of the phytase additive. Since phytase may be obtained from different sources, it would follow that different sources would result in different enzyme characteristics and therefore different efficacies (Onyango et al., 2005). The difference in characteristics include optimum $\mathrm{pH}$, thermostability, solubility, and resistance to hydrolysis. In addition, the dosage at which the exogenous phytase is included in the diet will alter its effects (Li et al., 2016; Shirley and Edwards, 2003). For a phytase additive to be optimized, it must also be thermally stable, as well as maintain phytase activity with the gastrointestinal tract of the animal (Nyannor et al., 2009). While commercially available phytase products have led to increased digestibility, tibia mineralization, and broiler performance, there is room for greater improvement and thus, more research. Determining an efficacious phytase source and dose, and identifying conditioning temperatures that may denature the enzyme, can lead to increased broiler performance and decreased feed cost. 


\section{Commercial Phytase Sources}

The varying characteristics and effectiveness of phytase supplements may be explained by factors such as the phytase source. There are many commercially available 6-phytase products that have shown to be effective in improving broiler performance. The inclusion of 6-phytases, such as phytase from the bacteria sources Escherichia coli or Buttiauxella, have been shown to improve broiler performance, as indicated by increased feed intake (FI), live weight gain (LWG), tibia ash percent and weight, and decreased feed conversion ratio (FCR; Cowieson et al., 2006; Walk et al., 2014). Pillai et al. (2006) found that phytase from Escherichia coli are more effective than fungal phytases at releasing phosphorus, leading to increased tibia ash percent and weight. Li and coauthors (2015) found that the inclusion of a phytase from Buttiauxella increased LWG, FI, tibia ash percent, and tibia ash weight compared to a negative control. While research seems to unanimously agree that both Escherichia coli and Buttiauxella phytases can be effective in improving broiler performance, there is a lack of data comparing the effectiveness of these two types of phytase.

Genetic modifications are being made to increase phytate-degrading activity in the plant seed itself as an alternative strategy for improving nutrient management in animal production. This concept was first introduced by Pen et al. (1993), who found that a phytase enzyme in tobacco seeds was able to maintain in vitro activity for an entire year after harvest. However, tobacco seeds are not a main component in poultry diets, so other options were explored. Soybeans expressing phytase were used by Denbow et al. (1998), who found the transgenic soybean was just as effective as phytase additive in improving broiler FI, LWG, and bone ash content. The disadvantage of using a transgenic soybean product is that soybeans are subjected to high thermal processing prior to their inclusion in the diet. Corn, however, is not subjected to such processing. Nyannor et al. (2009) 
concluded that a transgenic corn phytase can maintain a significant level of phytase activity and effectively dephosphorylate phytate. A study by Gao et al. (2013) found that phytase expressed as corn can be as efficacious as microbial phytases in improving phytate digestibility in laying hens. The use of transgenic phytase corn (TPC) may be more economically feasible than microbial phytases, since plants already constitute a larger land mass than microbial expression systems. However, corn is a mixer-added ingredient, meaning the phytase enzyme must be thermally stable in order to survive the pelleting process. Pelleting of the feed is necessary to decrease feed segregation and has been shown to increase broiler performance as opposed to mash diets. While transgenic phytase products may be promising, more research needs to be conducted regarding their stability and efficacy. It is also important to consider consumers' perceptions. Genetically-modified organisms (GMOs) are currently a controversial subject, and there is potential that consumers would not purchase TPC regardless of its efficacy.

\section{Inclusion Levels}

Perhaps equally important to the source of the phytase is the dose at which it is administered. Conflicting data exists about the optimal dosage for poultry feed. The universally accepted commercial recommendation is 500 FTU/kg (Shirley and Edwards, 2003). One phytase unit (FTU) may be defined as the quantity of enzyme required to liberate $1 \mu \mathrm{mol}$ of inorganic $\mathrm{P}$ per minute from an excess of $1.5 \mathrm{mM}$ sodium at $37^{\circ} \mathrm{C}$, with a $\mathrm{pH}$ of 5.5 (International Union of Biochemistry, 1979). While $500 \mathrm{FTU} / \mathrm{kg}$ is the current recommendation, research has been performed in an attempt to show that higher doses may be beneficial. 
Shirley and Edwards (2003) found that super dosing (>1,000 FTU/kg) increases amino acid digestibility and retention, and results in maximum broiler performance compared to lower doses in broiler chicks from d1-16. The authors concluded that phytase levels above commercial recommendation $(12,000 \mathrm{FTU} / \mathrm{kg})$ are required in order to make almost all (95\%) of the phytate $\mathrm{P}$ available for maximum utilization by chicks. This is in agreement with earlier work by Shirley and Edwards (2002), which found that the supplementation of phytase at 6,000 FTU/kg improved broiler performance, bone ash, and the utilization of phytate phosphorus. Walk et al. (2013) showed that feeding a diet with exogenous enzyme inclusion $>1500 \mathrm{FTU} / \mathrm{kg}$ to broilers from d0-21, resulted in almost complete hydrolysis of phytate and decrease in FCR. However, Walk and others did not observe any improvements in FI, LWG, or tibia ash content when supplementing a diet with 1500 FTU/kg versus $500 \mathrm{FTU} / \mathrm{kg}$.

In contrast, many studies have shown that phosphorus utilization plateaus at 500 FTU/kg (Simons et al., 1990; Huyghebaert et al., 1992). Research performed by Cowieson et al. (2006) showed that the amino acid digestibility of younger birds (d1-16) was maximized with the inclusion of 250-300 FTU/kg exogenous phytase. Insignificant improvement was found from adding phytase at levels above 600 FTU/kg. This is in agreement with Pieniazek et al. (2016), who found that when phytase inclusion $>250 \mathrm{FTU} / \mathrm{kg}$, there was little to no significance in increased amino acid digestibility. While the study did not observe an improvement in amino acid digestibility, phytase inclusion at $1,200 \mathrm{FTU} / \mathrm{kg}$ did result in increased FI, LWG, tibia ash percent, and tibia ash weight. In addition, Pieniazek and others found that phytase inclusion at 2,000 FTU/kg increased amino acid digestibility, FI, and LWG when birds were raised to $\mathrm{d} 42$. This leads to the theory that phytase supplementation at inclusions above commercial recommendations are only beneficial when provided to older birds. Nonetheless, the supplementation of phytase at levels above commercial recommendations provides 
inconsistent justification to support the additional cost. More research must be performed before commercial recommendations are modified.

\section{Conditioning Temperatures}

In addition to the phytate product source and dose, the method that the supplement is incorporated into the diet, i.e. mash or pelleted, will alter its effectiveness. When feed is pelleted, it is exposed to high temperatures, pressure, and steam. Phytase enzymes may be sprayed on to the feed postpelleting, but this method does not ensure mix uniformity throughout the diet or protect against nutrient segregation effects associated with feed attrition during auguring. Therefore, most phytase enzymes are added at the mixer. Loop et al. (2012) stated that mixer-added phytase products have the potential to be denatured during the pelleting process due to the exposure of heat, moisture, and pressure. Phytase enzymes may contain a carbohydrate-lipid coating, be genetically modified, or be selected due to heat stability, in an attempt to circumvent issues associated with denaturation during the pelleting process. Loop and others investigated heat-stable E. coli derived phytases, and found that as steam conditioning temperatures increased (up to $82^{\circ} \mathrm{C}$ ), phytase activity decreases. In addition, Loar et al. (2014) found that increasing conditioning temperatures (up to $96^{\circ} \mathrm{C}$ ) of broiler diets per se increased FCR and decreased amino acid digestibility.

There is argument that conditioning temperatures need to remain high, regardless of the effect on phytase activity. High temperatures aid in the destruction pathogens and anti-nutritive factors. High temperatures are also required for proper agglomeration of nutrients and for the attainment of high quality pellets (Thomas and van der Poel, 1996). Since the thermal stability of commercially 
available phytase products may vary drastically, more research needs to be conducted to determine what conditioning temperatures are appropriate.

\section{Conclusions and Future Research}

In conclusion, due to the diversity of phytase additives, it may not be feasible to create universally appropriate doses and conditioning temperatures. Much research is still required to justify the use of transgenic phytase corn over microbial phytase. In addition, 6-phytases need to be compared to each other to determine if one phytase is superior. Future research should address individual phytase products to create a range of appropriate conditioning temperatures and doses that produce maximal broiler performance and tibia mineralization.

\section{References}

1. Adeola, O. and J.S. Sands. 2003. Does supplemental dietary microbial phytase improve amino acid utilization? A perspective that it does not. J Anim. Sci. 81:78-85.

2. Bedford, M.R. and H. Schulze. 1998. Exogenous enzymes for pigs and poultry. Nut. Res. Rev. 11:91-114.

3. Bedford, M.R. 2000. Exogenous enzymes in monogastric nutrition- Their current value and future benefits. Anim. Feed Sci. Technol. 86(1-2): 1-13.

4. Biehl, R. R., D. H. Baker, and H.F. DeLuca. 1998. Activity of various hydroxylated vitamin D3 analogs for improving phosphorus utilization in chicks receiving diets adequate in vitamin D3. Br. Poult. Sci. 39:408-412. 
5. Cowieson, A.J., T. Acamovic, and M.R. Bedford. 2006. Supplementation of corn-soy-based diets with an Escherichia coli derived phytase: Effects on broiler chick performance and the digestibility of amino acids and metabolizability of minerals and energy. Poult. Sci. 85:13891397.

6. Denbow, D.M., E.A. Grabau, G.H. Lacey, E.T. Kornegay, D.R. Russell, and P.F. Umbeck. 1998. Soybeans transformed with a fungal phytase gene improve phosphorus availability for broilers. Poult Sci. 77:878-881.

7. Dilger, R.N., E.M. Onyango, J.S. Sands and O. Adeola. 2004. Evaluation of microbial phytase in broiler diets. Poult Sci. 83:962-970.

8. Gao, C.Q., C. Ji, L.H. Zhao, J.Y. Zhang, and Q.G. Ma. 2013. Phytase transgenic corn in nutrition of laying hens: Residual phytase activity and phytate phosphorus content in the gastrointestinal tract. Poult. Sci. 92:2923-2929.

9. Greiner, R., N.G. Carlsson, and M. Larsson Alminger. 2000. Stereospecificity of myo-inositol hexakisphosphate dephosphorylation by a phytate-degrading enzyme of Escherichia coli. Journal of Biotechnology 84:53-62.

10. Gurbuz Y., M. Cetin, and T. Sengul. 2009. Effect of phytase supplementation on performance, tibia ash, and serum $\mathrm{P}$ in broilers fed diets with different levels of phosphorus. $\mathrm{J}$ Appl. Anim. Res. 36:137-140.

11. Huyghebaert, G., G. de Groote, and C. Geerse. 1992. Effect of microbial phytase on the utilization of phosphorus by broiler chickens. 1. Effect on the availability of phosphorus and calcium. Rev. Agric. 45:217-228.

12. International Union of Biochemistry. 1979. Enzyme Nomenclature: Recommendation of the Nomenclature Committee of the International Union of Biochemistry. Academic Press, New York, NY.

13. Li, W., R. Angel, S.-W. Kim, E. Jimenez-Moreno, M. Proszkowiec-Weglarz, and P.W. Plumstead. 2015. Impact of response criteria (tibia ash weight vs. percent) on phytase relative non phytate phosphorus equivalence. Poult. Sci. 94:2228-2234.

14. Li, W., R. Angel, S.-W. Kim, K. Brady, S. Yu, and P.W. Plumstead. 2016. Impacts of dietary calcium, phytate, and nonphytate phosphorus concentrations in the presence of phytase on inositol hexakisphosphate (IP6) degradation in different segments of broilers digestive tract. Poult. Sci. 95:581-589.

15. Loar II, R.E., K.G.S. Wamsley, A. Evans, J.S. Moritz, and A. Corzo. 2014. Effects of varying conditioning temperature and mixer-added fat on feed manufacturing efficiency, 28- to 42day broiler performance, early skeletal effect, and true amino acid digestibility. J. Appl. Poult. Res. 23:444-455. 
16. Loop, S.A., K.G.S. Lilly, L.K. Shires, C.K. Gehring, K.R. Beaman, M.E. Persia, and J.S. Moritz. 2012. The phytase analytical activity of pelleted diets may not adequately describe efficacy in the bird. J. Appl. Polut. Res. 21:492-501.

17. Maenz, D. D. 2001. Enzymatic characteristics of phytases as they relate to their use in animal feeds. Pages 61-84 in Enzymes in Farm Animal Nutrition. M. R. Bedford and G. G. Partridge, ed. CABI Publishing, New York, NY.

18. National Research Council. 1994. Nutrient Requirements of Poultry. $9^{\text {th }}$ rev. ed. National Academy of Science, Washington, DC.

19. Nyannor, E.K.D., M.R. Bedford, and O Adeola. 2009. Corn expressing Escherichia coliderived phytase gene: Residual phytase activity and microstructure of digesta in broiler chicks. Poult. Sci. 88:1413-1420.

20. Onyango, E.M., M.R. Bedford, and O. Adeola. 2005. Phytase activity along the digestive tract of the broiler chick: A comparative study of an Escherichia coli-derived and Peniophora lycci phytase. Can. J. Anim. Sci. 85:61-68.

21. Pen. J., T.C. Verwoerd, P.A. van Paridon, R.F. Beudeker, P.J.M. van den Elzen, K. Geerse, J.D. van der Klis, H.A.J. Versteegh, A.J.J. van Ooyen, and A Hoekema. 1993. Phytasecontaining transgenic seeds as a novel feed additive for improved phosphorus utilization. Nat. Biotechnol. 11:811-814.

22. Pieniazek, J., K.A. Smith, M.P. Williams, M.K. Manangi, M. Vazquez-Anon, A. Solbak, M. Miller, and J.T. Lee. 2016. Evaluation of increasing levels of a microbial phytase in phosphorus deficient broiler diets via live broiler performance, tibia bone ash, apparent metabolizable energy, and amino acid digestibility. Poult. Sci. 00:1-13.

23. Pillai, P.B., t. O’Conner-Dennie, C.M. Owens, and J.L. Emmert. 2006. Efficacy of an Escherichia coli phytase in broilers fed adequate or reduced phosphorus diets and its effect on carcass characteristics. Poult. Sci. 85:1737-1745.

24. Ravindran, V., W.L. Bryden, and E.T. Kornegay. 1995. Phytates: Occurrence, bioavailability, and implications in poultry nutrition. Poult. Avian Biol. Rev. 6:125-143.

25. Sebastian, S., S.P. Touchburn, E.R. Chavez, and P.C. Lague. 1996. The effects of supplemental microbial phytase on the performance and utilization of dietary calcium, phosphorus, copper, and zinc in broiler chickens fed corn-soybean diets. Poult. Sci. 75:729736.

26. Sharpley, A. 1999. Agricultural Phosphorus, Water Quality, and Poultry Production: Are They Compatible? Poult. Sci. 78:660-673.

27. Shirley, R.B., and H.M Edwards, Jr. 2002. Dietary calcium affects phytase activity when phytase is supplemented in excess of industry standards. Poult. Sci. 81(Suppl. 1):11. (Abstr.).

28. Shirley, R.B. and H.M. Edwards, Jr. 2003. Graded levels of phytase past industry standards improves broiler performance. Poult. Sci. 82:671-680. 
29. Simons, P.C.M., H.A.J. Versteegh, A.W. Jongbloed, P.A. Kemme, P. Slump, K.D. Bos, M.G.E. Wolters, R.F. Beudeker, and G.J. Verschoor. 1990. Improvement of phosphorus availability by microbial phytase in broilers and pigs. Br. J. Nutr. 64:525-540.

30. Thomas, M., and A.F.B. van der Poel. 1996. Physical quality of pelleted animal feed. 1. Criteria for pellet quality. Anim. Feed Sci. Technol. 61:89-112.

31. Walk, C.L., M.R. Bedford, T.T. Santos, D. Paiva, J.R. Bradley, H. Wladecki, C. Honaker, and A.P. McElroy. 2013. Extra-phosphoric effects of superdoses of a novel microbial phytase. Poult. Sci. 92:719-725.

32. Walk, C.L., T.T. Santos, and M.R. Bedford. 2014. Influence of superdoses of a novel microbial phytase on growth performance, tibia ash, and gizzard phytate and inositol in young broilers. Poult. Sci. 93:1172-1177 


\title{
CHAPTER 2
}

The effect of varying levels of commercial and novel phytase products on broiler performance and tibia mineralization

\author{
V.B. Homan and J.S. Moritz
}




\section{SUMMARY}

Innovative phytase products may be cost effective for use in feeding commercial poultry. The objective of the study was to compare a Transgenic Phytase Corn (TPC) and a Granulated Bacterial Phytase (GBP) in mash diets on 21-D Hubbard x Cobb broiler chick performance, phosphorus equivalency values, and tibia mineralization. The experiment was arranged in a randomized complete block design with ten replications of nine treatments total. Treatments varied in nPP (Negative control - 0.2 (NC), Positive control - 0.4 (PC), 0.3, and 0.35), phytase product (TPC or GBP), and phytase dose $(500-3,000 \mathrm{FTU} / \mathrm{kg})$. Based on the multiple comparison of all treatments, the NC and PC affected performance variables as would be expected $(\mathrm{P}<0.05)$. A $2 \times 2$ factorial analysis was performed with the main effects of phytase activity and phytase product. The results of this analysis showed that increased phytase activity increased feed intake $(\mathrm{P}=0.0001)$. Additionally, phytase activity and product interacted to affect LWG $(\mathrm{P}=0.0473)$. The GBP LWG improvement due to increased activity was greater than the TPC LWG improvement due to increased activity. Broiler chicks provided GBP had improved FCR $(\mathrm{P}=0.0005)$ compared to chicks provided TPC. Phytase product and activity both affected tibia ash content $(\mathrm{P}=0.0001)$. Linear regression performed on $\mathrm{LWG}$ of diets increasing in $\mathrm{nPP}\left(\mathrm{R}^{2}=0.66\right)$, were used to demonstrate $3,000 \mathrm{FTU} / \mathrm{kg} \mathrm{nPP}$ equivalency of 0.07 and 0.20 for TPC and GBP respectively. Linear regression performed on tibia ash of diets increasing in $\mathrm{nPP}\left(\mathrm{R}^{2}=0.88\right)$, were used to demonstrate 3,000 FTU/kg nPP equivalency of 0.08 and 0.15 for TPC and GBP respectively. Calculated additions of 3,000 FTU/kg were analytically similar for TPC and GBP (2,800 and 3,100 FTU/kg, respectively). Phytase product efficacy differences may be due to dispersion of enzyme within mash. The transgenic phytase corn had a larger particle size in comparison to the granulated bacterial phytase. Despite a homogenous mix, broilers would still be less like to consume the fewer, larger particles of transgenic corn as opposed to the smaller, more 
frequent particles of granulated bacterial phytase. Differences may also be attributed to the general effectiveness of the expressed enzyme. The expression system of the granulated bacteria phytase may have been superior to that of the transgenic phytase corn. 


\section{DESCRIPTION OF PROBLEM}

Poultry receive the majority of their phosphorus in the form of Phytate (myo-inositol hexakisphosphate, IP6). Phytate is not easily digested, and it forms insoluble complexes with other nutrients. As a result, phosphorus is excreted in manure and subsequently spread on fields as a fertilizer, which has been implicated as having a potentially detrimental environmental effect (Biehl et al., 1998). Due to the reduced digestibility of cereal and oil seed phosphorus, excessive levels of phosphorus must be included in the diet, which increases both the potential for environmental pollution and feed cost. Exogenous phytase is able to make otherwise inaccessible phosphorus available to poultry by hydrolyzing the phytate molecule (Ravindran et al., 1995). Therefore, exogenous phytase is added to most commercial broiler diets in order to improve nutrient availability, decrease costs, and reduce environmental pollution (Bedford, 2000; Dilger et al., 2004). Exogenous phytase supplementation has been shown to improve broiler performance, via increased weight gain, nutrient utilization, and tibia ash percentages (Gurbuz et al., 2009; Sebastian et al., 1996). In addition, as an alternative to common phytase feed additives that are commercially available, genetic modifications are being made to corn to allow for expression of phytase enzyme (Nyannor et al., 2009).

While commercially available phytase products have led to improved nutrient digestibility, tibia mineralization, and broiler performance, there are additional factors that may affect efficiency. For example, the dosage at which the phytase product is included will alter its effects (Cowieson et al., 2006). The inclusion of exogenous phytase at or above 1,000 FTU/kg has been referred to as superdosing, and has been shown to further improve nutrient absorption and broiler performance (Shirley and Edwards, 2003; Walk et al., 2013). In addition, there is little research comparing the effectiveness of genetically modified transgenic phytase corn (TPC) to commercially available 
phytase enzymes. The objective of the current study was to evaluate the effect of phytase product and inclusion level on Hubbard x Cobb 21-d broiler performance and tibia mineralization. 


\section{MATERIALS AND METHODS}

\section{Dietary Treatments}

The two phytase products evaluated were a Granulated Bacterial Phytase (GBP) created by a genetically modified strain of the yeast species Pichia pastoris and an E. coli-derived phytase expressed in Transgenic Phytase Corn (TPC). Treatments used to establish effects of increasing nonphytate phosphorus (nPP) included a negative control (NC) diet containing $0.2 \% \mathrm{nPP}$ via dicalcium phosphate $(\mathrm{DCP}), \mathrm{NC}+0.1 \% \mathrm{nPP}$ via $\mathrm{DCP}, \mathrm{NC}+0.15 \% \mathrm{nPP}$ via $\mathrm{DCP}$, and a positive control $(\mathrm{PC})$ that contained $0.4 \% \mathrm{nPP}$ via DCP. Additional treatments containing phytase included 500, 1000, or $3000 \mathrm{FTU} / \mathrm{kg} \mathrm{GBP}+\mathrm{NC}$, and 500 or $3000 \mathrm{FTU} / \mathrm{kg}$ TPC + NC. All treatments consisted of corn and soybean-based mash diets (Table 1). There were nine dietary treatments total.

\section{Feed Manufacture}

Feed manufacture was conducted at the West Virginia University pilot feed mill. All diets were batched and mixed in one day. Two master batches were manufactured. One batch contained $0.2 \% \mathrm{nPP}(\mathrm{NC})$ and the other contained $0.4 \% \mathrm{nPP}(\mathrm{PC})$. Dietary treatments devoid of phytase were manufactured using one master batch or a blend of each master batch. Dietary treatments containing phytase were manufactured using the NC master batch.

Phytase inclusions for treatments were based on manufacturer supplied data (GBP treatments $=5,085$ FTU/g and TPC treatments = 3,345 FTU/g). Washed builders sand was used to balance phytase inclusion of the different products and levels to a $0.1 \%$ total diet inclusion (Table 1 ). In order to improve homogeneity of the final mix, phytase product, sand, and $5 \mathrm{lbs}$. of ground corn were mixed for ten minutes in a 4.73-liter Hobart mixer [11] prior to final treatment batching and mixing. Each dietary treatment was mixed for ten minutes in a one-ton vertical screw Easy Automation Inc. mixer 
[12]. This mix time was chosen because it has been shown to produce a homogenized diet, meaning it achieves a nutrient coefficient of variation of less than 10\% (Reese et al. 2016). Multiple samples of each treatment were collected and pooled prior to analysis of crude protein (Kjeldahl analysis), total calcium (AOAC method 927.02), total phosphorus (AOAC method 964.06), phytic acid (AOAC method 986.1) and phytase (AOAC method 2000.12).

\section{Broiler Performance and Bone Mineralization}

A total of 900 straight-run Hubbard x Cobb 500 broilers were fed the dietary treatments for 21 days. The lighting program followed 23L:1D from d1 to 7, and 20L:4D from d8 to 21. Feed and water were provided for ad libitum consumption. Brooding temperature was maintained to maximize bird comfort. Birds were cared for according to West Virginia University Animal Care and Use Committee Guidelines. Feed intake (FI), live weight gain (LWG), mortality corrected feed conversion ratio (FCR), and mortality were calculated for the 21-d growth period.

On d 21, all birds were euthanized via cervical dislocation. Right tibiae were excised and used to determine ash percentage. Tibiae were dried for $24 \mathrm{~h}$ at $105^{\circ} \mathrm{C}$. Fat was removed via extraction with petroleum ether over a $16 \mathrm{~h}$ period. Bones were weighed and then ashed at $600^{\circ} \mathrm{C}$ for $18 \mathrm{~h}$. Ash weight was recorded and used to determine ash percent.

\section{Statistical Analysis}

Bird performance and tibia measures were analyzed using the PROC GLM procedure of Statistical Analysis System (SAS) [14]. Variables were analyzed in a 2 x 2 factorial arrangement with the main effects of phytase product and phytase activity within a randomized complete block design. The experimental unit was a pen of ten broilers. Significance was established at $\alpha=0.05$. Fisher's LSD multiple comparison test was used to separate means of all nine treatments. Phosphorus 
equivalency values were determined using linear regression for live weight gain, feed intake, feed conversion ratio, and tibia mineralization. 


\section{RESULTS AND DISCUSSION}

Upon analysis, calculated additions of 500 and 3,000 FTU/kg were analytically similar for TPC and GBP (TPC=290 and 2,800 FTU/kg and GBP=500 and 3,100 FTU/kg, Table 1).

Performance variables and tibia mineralization are presented in Table 2. Increased phytase activity increased feed intake $(\mathrm{P}<0.0001)$. This is in agreement with Pieniazek, et al (2016), who found that increasing phytase levels increases feed intake, body weight, and tibia mineralization. Phytase product had no effect on feed intake. Nyannor et al. (2008) found no difference in FI, LWG, or tibia ash percent when comparing a TPC product to the commercially available phytase Quantum (AB Vista Feed Ingredients, Marlborough, UK), both with an inclusion of 3,650 FTU/kg. Phytase activity and product interacted to affect LWG $(\mathrm{P}=0.0473)$. The inclusion of phytase at 3,000 FTU/kg resulted in an increased LWG when compared to inclusion at $500 \mathrm{FTU} / \mathrm{kg}$; however, the GBP improvement was greater than TPC. There was no effect of phytase activity on FCR $(\mathrm{P}=0.7166)$. This is in agreement with Waldroup et al. (2000), who found that increases in LWG correspond proportionately to FI, making it uncommon to find improved FCR when the dietary P deficiency is alleviated. The GBP product resulted in a lower FCR $(\mathrm{P}=0.0005)$ than the TPC product. The inclusion of phytase at 3,000 FTU/kg resulted in increased tibia ash content $(\mathrm{P}=0.0001)$ when compared to inclusion at 500 FTU/kg. This is in agreement with Manobhavan et al (2005), who found that superdoses of phytase result in higher tibia ash content when compared to inclusion at 500 FTU/kg. Cowieson et al. (2006) found similar results, stating that phytase concentrations $>1200$ FTU/kg result in higher bone ash content than when provided at 250 or 500 FTU/kg. Broiler chicks provided the GBP diet resulted in higher tibia ash percent $(\mathrm{P}=0.0001)$. This is in disagreement with Nyannor and others (2008), however they used a different phytase product (Quantum), their TPC product had a higher phytase activity than Quantum (3,300 and 2,700 FTU/kg, respectively), and they did not provide feed 
manufacture data. Feeding a mash versus pellet diet could cause different results. Mortality did not exceed $4 \%$ for any treatment.

Linear regression performed on LWG of diets increasing in $\mathrm{nPP}\left(\mathrm{R}^{2}=0.66\right)$, were used to demonstrate 3,000 FTU/kg nPP equivalency of 0.07 and 0.20 for TPC and GBP respectively (Table 3). Manobhavan et al. (2015) concluded that the inclusion of phytase supplementation at 2,500 and 5,000 FTU/kg improved FI and LWG (P=0.001). Augspurger and Baker (2004) concluded that the addition of exogenous phytase at high levels can hydrolyze nearly $100 \%$ of phytate $\mathrm{P}$ in broiler chicks. Linear regression performed on tibia ash of diets increasing in $\mathrm{nPP}\left(\mathrm{R}^{2}=0.88\right)$, were used to demonstrate 3,000 FTU/kg nPP equivalency of 0.08 and 0.15 for TPC and GBP respectively. Differences in expression systems of the TPC and GBP may affect their efficacy. Additionally, particle size of the TPC product may have affected enzyme dispersion.

\section{CONCLUSIONS}

1) Providing broiler chicks mash diets with GBP resulted in increased broiler performance and tibia mineralization compared to broiler chicks provided mash diets with TPC. These results may be attributed to variations in dispersion of enzyme within the diet. The transgenic phytase corn has a larger particle size than the granulated bacterial phytase. Despite a homogenous mix, broilers would still be less like to consume the fewer, larger particles of transgenic corn as opposed to the smaller, more frequent particles of granulated bacterial phytase. Differences may also be attributed to the general effectiveness of the expressed enzyme. The expression system of the granulated bacteria phytase may have been superior to that of the transgenic phytase corn. 
2) The inclusion of a commercial phytase at $3,000 \mathrm{FTU} / \mathrm{kg}$ increased broiler performance and tibia mineralization compared to inclusion at $500 \mathrm{FTU} / \mathrm{kg}$. These results may be due to a greater reduction of phytate, alleviating anti-nutrient effects.

\section{REFERENCES AND NOTES}

1. Biehl, R. R., D. H. Baker, and H.F. DeLuca. 1998. Activity of various hydroxylated vitamin D3 analogs for improving phosphorus utilization in chicks receiving diets adequate in vitamin D3. Br. Poult. Sci. 39:408-412

2. Ravindran, V., W.L. Bryden, and E.T. Kornegay. 1995. Phytates: Occurrence, bioavailability, and implications in poultry nutrition. Poult. Avian Biol. Rev. 6:125-143.

3. Bedford, M.R. 2000. Exogenous enzymes in monogastric nutrition- Their current value and future benefits. Anim. Feed Sci. Technol. 86(1-2): 1-13

4. Dilger, R.N., E.M. Onyango, J.S. Sands and O. Adeola. 2004. Evaluation of microbial phytase in broiler diets. Poult Sci. 83:962-970.

5. Gurbuz Y., M. Cetin, and T. Sengul. 2009. Effect of phytase supplementation on performance, tibia ash, and serum $\mathrm{P}$ in broilers fed diets with different levels of phosphorus. $\mathrm{J}$ Appl. Anim. Res. 36:137-140.

6. Sebastian, S., S.P. Touchburn, E.R. Chavez, and P.C. Lague. 1996. The effects of supplemental microbial phytase on the performance and utilization of dietary calcium, phosphorus, copper, and zinc in broiler chickens fed corn-soybean diets. Poult. Sci. 75:729736.

7. Nyannor, E.K.D., M.R. Bedford, and O Adeola. 2009. Corn expressing Escherichia coliderived phytase gene: Residual phytase activity and microstructure of digesta in broiler chicks. Poult. Sci. 88:1413-1420.

8. Cowieson, A.J., T. Acamovic, and M.R. Bedford. 2006. Supplementation of corn-soy-based diets with an Escherichia coli derived phytase: Effects on broiler chick performance and the digestibility of amino acids and metabolizability of minerals and energy. Poult. Sci. 85:13891397.

9. Shirley, R.B. and H.M. Edwards Jr. 2003. Graded levels of phytase past industry standards improves broiler performance. Poult. Sci. 82:671-680. 
10. Walk, C.L., M.R. Bedford, T.T. Santos, D. Paiva, J.R. Bradley, H. Wladecki, C. Honaker, and A.P. McElroy. 2013. Extra-phosphoric effects of superdoses of a novel microbial phytase. Poult. Sci. 92:719-725.

11. Hobart, Troy, OH.

12. MFP Vertical Mixer, Easy Automation Inc., Welcome, MN.

13. Reese, D.A., K.L. Foltz, J.S. Moritz. 2016. Effect of mixing and sampling method on pelleted feed nutrient analysis and diet formulation validation. J. Appl. Poult. Res. Accepted for publication.

14. SAS institute. 2013. The SAS system for Windows 2013. Release 9.3 SAS Inst. Inc., Cary, NC.

15. Pieniazek, J., K.A. Smith, M.P. Williams, M.K. Manangi, M. Vazquez-Anon, A. Solbak, M. Miller, and J.T. Lee. 2016. Evaluation of increasing levels of a microbial phytase in phosphorus deficient broiler diets via live broiler performance, tibia bone ash, apparent metabolizable energy, and amino acid digestibility. Poult. Sci. 00:1-13.

16. Nyannor, E.K.D., and O. Adeola. 2008. Corn expressing an Escherichia coli-derived phytase gene: Comparative evaluation study in broiler chicks. Poult. Sci. 87:2015-2022.

17. Waldroup P.W., J.H.Kersey, E.A. Saleh, C.A. Fritts, F.Yan, H.L. Stilborn, R.C. Crum Jr., and V. Raboy. 2000. Nonphytate phosphorus requirement and phosphorus excretion of broiler chicks fed diets composed of normal or high available phosphate corn with and without microbial phytase. Poult Sci. 79:1451-1459.

18. Manobhavan, M., A.V. Elangovan, M. Sridhar, D. Shet, S. Ajith, D.T. Pal, and N.K. Gowda. 2015. Effect of super dosing of phytase on growth performance, ileal digestibility and bone characteristics in broilers fed corn-soya-based diets. J Anim. Physiol. Anim. Nutr. 100:93100.

19. Augspurger, N. R., and D. H. Baker. 2004. High dietary phytase levels maximize phytatephosphorus utilization but do not affect protein utilization in chicks fed phosphorus- or amino acid-deficient diets. J. Anim. Sci. 82:1100- 1107. 
Table 1. Ingredients, calculated nutrient content, and analyzed nutrient content of diets provided to Hubbard $\mathrm{x}$ Cobb 500 broilers from 1-21 d of age.

\begin{tabular}{|c|c|c|c|c|c|c|c|c|c|}
\hline Ingredient (\%) & \multicolumn{8}{|c|}{ NC } & PC \\
\hline Corn & \multicolumn{8}{|c|}{55.45} & 54.46 \\
\hline Soybean meal $(48 \%)$ & \multicolumn{8}{|c|}{37.97} & 38.22 \\
\hline Soybean oil & \multicolumn{8}{|c|}{3.02} & 3.30 \\
\hline Limestone & \multicolumn{8}{|c|}{1.68} & 1.06 \\
\hline DL-Methionine & \multicolumn{8}{|c|}{0.48} & 0.48 \\
\hline Dicalcium phosphate & \multicolumn{8}{|c|}{0.37} & 1.45 \\
\hline Salt & \multicolumn{8}{|c|}{0.29} & 0.29 \\
\hline Vitamin mineral premix ${ }^{1}$ & \multicolumn{8}{|c|}{0.25} & 0.25 \\
\hline Sodium Bicarbonate & \multicolumn{8}{|c|}{0.15} & 0.15 \\
\hline Lysine & \multicolumn{8}{|c|}{0.12} & 0.12 \\
\hline Threonine & \multicolumn{8}{|c|}{0.12} & 0.12 \\
\hline Sand & \multicolumn{8}{|c|}{0.10} & 0.10 \\
\hline \multicolumn{10}{|c|}{ Calculated Nutrients } \\
\hline ME (kcal/kg) & \multicolumn{8}{|c|}{1,361} & 1,361 \\
\hline Crude Protein (\%) & \multicolumn{8}{|c|}{22.27} & 22.33 \\
\hline Digestible Lysine (\%) & \multicolumn{8}{|c|}{1.20} & 1.20 \\
\hline Digestible Methionine & \multicolumn{8}{|c|}{0.54} & 0.54 \\
\hline Digestible Methionine+ Cystine & \multicolumn{8}{|c|}{1.15} & 1.14 \\
\hline Digestible Threonine (\%) & \multicolumn{8}{|c|}{0.84} & 0.84 \\
\hline Digestible Arginine (\%) & \multicolumn{8}{|c|}{1.39} & 1.40 \\
\hline Digestible Tryptophan (\%) & \multicolumn{8}{|c|}{0.24} & 0.24 \\
\hline Calcium (\%) & \multicolumn{8}{|c|}{0.80} & 0.80 \\
\hline Available Phosphorus (\%) & \multicolumn{8}{|c|}{0.20} & 0.40 \\
\hline Sodium $(\%)$ & \multicolumn{8}{|c|}{0.17} & 0.17 \\
\hline \multicolumn{10}{|c|}{ Analyzed Nutrients } \\
\hline & $\begin{array}{l}\mathrm{NC}= \\
0.2 \% \\
\mathrm{nPP}\end{array}$ & $\begin{array}{c}\mathrm{NC}+0.1 \% \\
\mathrm{nPP}\end{array}$ & $\begin{array}{c}\mathrm{NC}+ \\
0.15 \% \mathrm{nPP}\end{array}$ & $\begin{array}{l}\text { NC }+500 \\
\text { FTU GBP }\end{array}$ & $\begin{array}{l}\text { NC }+1000 \\
\text { FTU GBP }\end{array}$ & $\begin{array}{l}\text { NC }+3000 \\
\text { FTU GBP }\end{array}$ & $\begin{array}{l}\mathrm{NC}+500 \\
\text { FTU TPC }\end{array}$ & $\begin{array}{l}\text { NC }+3000 \\
\text { FTU TPC }\end{array}$ & $\begin{array}{l}\mathrm{PC}=\mathrm{NC}+ \\
0.2 \% \mathrm{nPP}\end{array}$ \\
\hline Crude Protein (\%) & 21.2 & 19.6 & 21.1 & 20.5 & 21.1 & 19.5 & 20.7 & 21.1 & 19.9 \\
\hline Calcium $(\%)$ & 0.72 & 0.679 & 0.903 & 0.807 & 0.840 & 0.830 & 0.773 & 0.847 & 0.74 \\
\hline Non-Phytate Phosphorus ${ }^{2}(\%)^{2}$ & 0.20 & 0.29 & 0.35 & 0.24 & 0.19 & 0.20 & 0.21 & 0.21 & 0.40 \\
\hline Phytase (ftu/kg) & -- & -- & -- & 500 & 1000 & 3100 & 290 & 2800 & -- \\
\hline \multicolumn{10}{|c|}{$\begin{array}{l}{ }^{1} \text { Supplied per kg of diet: manganese, } 0.02 \% \text {; zinc } 0.02 \% \text {; iron, } 0.01 \% \text {; copper, } 0.0025 \% \text {; iodine, } 0.0003 \% \text {; selenium, } 0.00003 \% \text {; folic } \\
\text { acid, } 0.69 \mathrm{mg} \text {; choline, } 386 \mathrm{mg} \text { riboflavin, } 6.61 \mathrm{mg} \text {; biotin, } 0.03 \mathrm{mg} \text {; vitamin } \mathrm{B}_{6}, 1.38 \mathrm{mg} \text {; niacin, } 27.56 \mathrm{mg} \text {; pantothenic acid, } 6.61 \mathrm{mg} \text {; } \\
\text { thiamine, } 2.20 \mathrm{mg} \text {; manadione, } 0.83 \mathrm{mg} \text {; vitamin } \mathrm{B}_{12}, 0.01 \mathrm{mg} \text {; vitamin E, } 16.53 \mathrm{IU} \text {; vitamin } \mathrm{D}_{3}, 2133 \mathrm{ICU} \text {; vitamin A, } 7716 \mathrm{IU} \text {. } \\
{ }^{2} \mathrm{nPP}=\text { Total Phosphorus- (phytic acid x } 0.282 \text { ) } \\
\text { R. Angel et al. } 2002\end{array}$} \\
\hline
\end{tabular}


Table 2: Statistical comparison of all dietary treatments as well as the factorial arrangement of treatments on $21 \mathrm{~d}$ Hubbard $\mathrm{x}$ Cobb straight-run broiler performance.

\begin{tabular}{|c|c|c|c|c|c|c|c|c|}
\hline Enzyme & Activity & $\begin{array}{l}\text { Percent AP } \\
\text { due to } \\
\text { Dicalcium P }\end{array}$ & $\begin{array}{l}\text { Starting } \\
\text { Pen } \\
\text { Weight } \\
\text { (kg) }\end{array}$ & $\begin{array}{c}\text { Feed } \\
\text { Intake/pen } \\
\text { (kg) }\end{array}$ & $\begin{array}{l}\text { LWG/bird }{ }^{1} \\
\text { (kg) }\end{array}$ & $\begin{array}{c}F^{F C R^{2}} \\
(\mathrm{~kg} / \mathrm{kg})\end{array}$ & $\begin{array}{l}\text { Percent } \\
\text { Mortality } \\
\text { (\%) }\end{array}$ & $\begin{array}{c}\text { Percent } \\
\text { Tibia Ash } \\
\text { (\%) }\end{array}$ \\
\hline No & No & 0.2 & 0.451 & $9.118^{\mathrm{C}}$ & $0.585^{\mathrm{E}}$ & $1.524^{\mathrm{AB}}$ & 4 & $26.434^{E}$ \\
\hline No & No & 0.3 & 0.451 & $10.090^{A B}$ & $0.697^{B}$ & $1.436^{\mathrm{BC}}$ & 2 & $32.1401^{C}$ \\
\hline No & No & 0.35 & 0.451 & $10.423^{A}$ & $0.712^{B}$ & $1.461^{\mathrm{BC}}$ & 0 & $33.714^{\mathrm{B}}$ \\
\hline No & No & 0.4 & 0.448 & $10.562^{A}$ & $0.761^{\mathrm{A}}$ & $1.382^{C}$ & 1 & $35.0136^{A}$ \\
\hline GBP & $500 \mathrm{FTU} / \mathrm{kg}$ & 0.2 & 0.453 & $9.396^{\mathrm{BC}}$ & $0.640^{D}$ & $1.448^{\mathrm{BC}}$ & 1 & $29.535^{D}$ \\
\hline GBP & 1,000 FTU/kg & 0.2 & 0.449 & $10.221^{A}$ & $0.681^{\mathrm{BC}}$ & $1.503^{B}$ & 1 & $31.523^{C}$ \\
\hline GBP & $3,000 \mathrm{FTU} / \mathrm{kg}$ & 0.2 & 0.451 & $10.555^{\mathrm{A}}$ & $0.763^{A}$ & $1.398^{\mathrm{C}}$ & 4 & $33.592^{B}$ \\
\hline TPC & 500 FTU/kg & 0.2 & 0.453 & $8.993^{C}$ & $0.584^{\mathrm{E}}$ & $1.537^{\mathrm{AB}}$ & 3 & $26.783^{\mathrm{E}}$ \\
\hline TPC & 3,000 FTU/kg & 0.2 & 0.452 & $10.488^{A}$ & $0.649^{C D}$ & $1.616^{\mathrm{A}}$ & 0 & $30.438^{D}$ \\
\hline ANO & VA P-value & & 0.2041 & 0.0001 & 0.0001 & 0.004 & 0.1186 & 0.0001 \\
\hline & SEM $^{3}$ & & 0.0013 & 0.2496 & 0.0128 & 0.0362 & 1.2070 & 0.3419 \\
\hline \multicolumn{9}{|c|}{ Marginal Means-Product } \\
\hline \multicolumn{3}{|c|}{ GBP } & 0.452 & 9.976 & $0.701^{A}$ & $1.423^{\mathrm{B}}$ & 2.500 & $31.5637^{A}$ \\
\hline \multicolumn{3}{|c|}{ TPC } & 0.452 & 9.740 & $0.616^{\mathrm{B}}$ & $1.576^{\mathrm{A}}$ & 1.500 & $28.6100^{B}$ \\
\hline \multicolumn{3}{|c|}{ SEM } & 0.0011 & 0.2133 & 0.0098 & 0.0285 & 0.8660 & 0.3429 \\
\hline \multicolumn{9}{|c|}{ Marginal Means-Activity } \\
\hline \multicolumn{3}{|c|}{$500 \mathrm{FTU} / \mathrm{kg}$} & 0.453 & $9.195^{\mathrm{B}}$ & $0.612^{\mathrm{B}}$ & 1.492 & 2.000 & $28.1589^{B}$ \\
\hline \multicolumn{3}{|c|}{ 3,000 FTU/kg } & 0.451 & $10.521^{\mathrm{A}}$ & $0.706^{A}$ & 1.507 & 2.000 & $32.0148^{A}$ \\
\hline \multicolumn{3}{|c|}{ SEM } & 0.0011 & 0.2133 & 0.0098 & 0.0285 & 0.8660 & 0.3429 \\
\hline \multicolumn{9}{|c|}{ Main Effects and Interactions } \\
\hline \multicolumn{3}{|c|}{ Product } & 0.7735 & 0.4404 & 0.0001 & 0.0005 & 0.4196 & 0.0001 \\
\hline \multicolumn{3}{|c|}{ Activity } & 0.4298 & 0.0001 & 0.0001 & 0.7166 & 1.000 & 0.0001 \\
\hline \multicolumn{3}{|c|}{ Product x Activity } & 0.7554 & 0.5806 & 0.0473 & 0.1212 & 0.0193 & 0.6819 \\
\hline
\end{tabular}

${ }^{1}$ LWG $=$ Live Weight Gain

${ }^{2} \mathrm{FCR}=$ Feed Conversion Ratio, corrected for mortality

${ }^{3} \mathrm{SEM}=$ Standard Error of the Mean 
Table 3. Phosphorus equivalency values calculated from standard curve linear regression using Dicalcium Phosphorus.

\begin{tabular}{|c|c|c|c|c|c|c|c|c|}
\hline Treatment & $\begin{array}{l}\text { Linear } \\
\text { derived } \\
\text { Calc nPP } \\
\text { (\%) LWG }{ }^{1}\end{array}$ & $\begin{array}{l}\text { LWG } \\
\text { Phosphorus } \\
\text { Equivalency } \\
\text { Value }\end{array}$ & $\begin{array}{l}\text { Linear } \\
\text { derived } \\
\text { Calc nPP } \\
(\%) \text { FI }^{2}\end{array}$ & $\begin{array}{c}\text { FI } \\
\text { Phosphorus } \\
\text { Equivalency } \\
\text { Value }\end{array}$ & $\begin{array}{l}\text { Linear } \\
\text { derived } \\
\text { Calc nPP } \\
\text { (\%) FCR }{ }^{3}\end{array}$ & $\begin{array}{c}\text { FCR } \\
\text { Phosphorus } \\
\text { Equivalency } \\
\text { Value }\end{array}$ & $\begin{array}{c}\text { Linear derived } \\
\text { Calc nPP (\%) } \\
\text { Tibia Ash } \\
\text { Percent }^{4}\end{array}$ & $\begin{array}{c}\text { Tibia Ash (\%) } \\
\text { Phosphorus } \\
\text { Equivalency } \\
\text { Value }\end{array}$ \\
\hline $\begin{array}{l}\text { GBP } 500 \\
\text { FTU/kg }\end{array}$ & 0.26 & 0.06 & 0.23 & 0.03 & 0.32 & 0.12 & 0.26 & 0.06 \\
\hline $\begin{array}{l}\text { GBP } 1000 \\
\text { FTU/kg }\end{array}$ & 0.30 & 0.10 & 0.34 & 0.14 & 0.23 & 0.03 & 0.31 & 0.11 \\
\hline $\begin{array}{c}\text { GBP } 3000 \\
\text { FTU/kg }\end{array}$ & 0.40 & 0.20 & 0.38 & 0.18 & 0.40 & 0.20 & 0.35 & 0.15 \\
\hline $\begin{array}{l}\text { TPC } 500 \\
\text { FTU/kg }\end{array}$ & 0.19 & 0 & 0.17 & 0 & 0.18 & 0 & 0.20 & 0 \\
\hline $\begin{array}{c}\text { TPC } 3000 \\
\text { FTU/kg }\end{array}$ & 0.27 & 0.07 & 0.37 & 0.17 & 0.05 & 0 & 0.28 & 0.08 \\
\hline \multicolumn{9}{|c|}{$\begin{array}{l}{ }^{1} \text { Calculated } n P P \text { values derived from the linear regression of Live Weight Gain for the standard curve }(L W G-0.41981) / 0.86087 \\
=\text { calc. } n P P, R^{2}=0.6645 \\
{ }^{2} \text { Calculated } n P P \text { values derived from the linear regression of Feed Intake for the standard curve }(F I-7.71777) / 7.45832=\text { calc. } \\
n P P, R^{2}=0.2536 \\
{ }^{3} \text { Calculated } n P P \text { values derived from the linear regression of Feed Conversion Ratio for the standard curve }(F C R-1.64676) /- \\
0.62663=\text { calc. } n P P, R^{2}=0.1373 \\
{ }^{4} \text { Calculated } n P P \text { values derived from the linear regression of Tibia Ash \% for the standard curve }(\text { Tibia Ash } \%-18.22012) / 43.53670 \\
=\text { calc. } n P P, R^{2}=0.8782\end{array}$} \\
\hline
\end{tabular}




\section{CHAPTER 3}

The effect of diets varying in commercial phytase product subjected to increasing steam conditioning temperature on broiler performance and tibia mineralization

V.B. Homan and J.S. Moritz 


\section{SUMMARY}

Phytases are commonly added to diet formulations prior to pelleting to support phosphorus requirements in broilers. Commercial phytase products vary in thermal stability, site of action, mode of action, and manufacturer suggested protocols for determining activity. The objective of this study was to evaluate three commercial 6-phytase products within a phosphorus deficient corn and soybean meal based diet subjected to increasing steam conditioning temperature on broiler performance and tibia mineralization. Commercial phytase products included a Buttiauxella phytase expressed in Trichoderma reesei (B Trich), an E. coli phytase expressed in Pichia pastoris (E Pichia), and an E. coli phytase expressed in Trichoderma reesei (E Trich). Conditioning temperatures included 82,88 , and $93^{\circ} \mathrm{C}$ for a duration of 10 seconds prior to extrusion through a 4.7 x $38 \mathrm{~mm}$ pellet die. Commercial phytase products were analyzed for activity using the AOAC 2000.12 method at two different laboratories. The lower obtained activity was utilized to include each product at 1,000 FTU/kg of the diet prior to pelleting. Post extrusion, diets were ground to eliminate any variations in feed form and stored in a dehumidified room to ensure diets were of a similar moisture level, i.e. 12 percent. Diets containing the three commercial phytase products and a negative control diet without phytase were subjected to each conditioning treatment and fed to eight replicate raised wire cages of 10 Hubbard x Cobb straight-run broiler chicks for $20 \mathrm{~d}$. Treatments were blocked by cage locations within room. Broiler performance and tibia mineralization were analyzed using a $4 \times 3$ factorial arrangement within a randomized complete block design. The main effect product was significant for feed intake (FI), live weight gain (LWG) and feed conversion ratio (FCR). Broilers fed diets without phytase had the lowest FI and LWG $(\mathrm{P}<0.05)$. Broilers fed E Trich had the highest FI and LWG $(\mathrm{P}<0.05)$. Broilers fed B Trich and E Pichia had lower FCR 
compared to broilers fed diets without phytase and E Trich fed broilers were not distinguishable from other treatments $(\mathrm{P}<0.05)$. The main effect conditioning temperature was significant for FI and LWG. Increased conditioning temperature sequentially decreased both FI and LWG $(\mathrm{P}<0.05)$. Main effect interactions were not apparent $(\mathrm{P}>0.05)$. Commercial products demonstrated differences in supporting the phosphorus requirement in broilers and increasing conditioning temperature was detrimental to broiler performance. Increased conditioning temperature may have decreased nutrient availability per se, denatured phytase products, or both factors contributed to performance detriment. 


\section{DESCRIPTION OF THE PROBLEM}

Phytate (myo-inositol hexakisphosphate, IP6) makes up 2/3 of the phosphorus (P) provided in poultry diets (Eeckhout and DePaepe, 1994; Harland and Oberleas, 1999; Adeola and Sands, 2003). Phytate forms insoluble complexes with other nutrients, and poultry lack the endogenous enzymes necessary for the effective hydrolysis of phytate (Adeola and Sands, 2003; Bedford and Schulze, 1998). Phytase has the ability to hydrolyze phytate, making otherwise inaccessible phosphorus available to the bird (Ravindran et al., 1995). Microbial phytases are classified based on the site of initial phytate hydrolysis. A 6-phytase will dephosphorylate phytate in a sequential way, beginning by removing iP from the sixth position on the phytic acid molecule (Greiner et al., 2000).

Exogenous phytase supplementation has been shown to decrease feed cost, as well as improve broiler performance (Bedford, 2000). These improvements are indicated by increased weight gain, feed intake, Phosphorus utilization, and tibia mineralization (Gurbuz et al., 2009; Angel et al., 2002). Specifically, the addition of a 6-phytase at 500 FTU/kg has been shown to improve feed intake and bone mineralization (Pieniazek et al., 2016). Although research has shown effects based on inclusions of $500 \mathrm{FTU} / \mathrm{kg}$, activity inclusion of 1,000 FTU/kg was chosen for this study. Considered a super-dose, 1,000 FTU/kg was selected so that even if partial inactivation of the enzyme occurred, performance results would still be demonstrated in comparison to the negative control.

Phytase enzymes may be sprayed onto the feed post-pelleting, but this method does not ensure mix uniformity throughout the diet or protect against nutrient segregation effects. Therefore, most phytase enzymes are added at the mixer. In order for mixer-added exogenous phytase products to be efficacious in pelleted feed, they must be thermally stable. Phytase 
products may contain a carbohydrate-lipid coating, be genetically modified, or be specifically selected for heat stability, in an attempt to circumvent issues associated with denaturation during the pelleting process. Increasing steam conditioning temperatures results in decreased enzyme activity (Loop et al. 2012). It has also been shown that when conditioning temperature increases (from 74 to $96^{\circ} \mathrm{C}$ ), feed conversion ratio (FCR) increases and amino acid digestibility decreases (Loar et al., 2014). Several researchers have proposed target conditioning temperatures of 80$85^{\circ} \mathrm{C}$ (Jones and Richardson, 2004; Veldman et al., 1995). Equipment, ambient conditioning temperature, and nutrient composition affect the ability to condition feed at higher temperatures. However, conditioning temperature of $82^{\circ} \mathrm{C}$ can generally be obtained. Research focusing on thermal stability and pellet quality often condition feed at $88^{\circ} \mathrm{C}$. Since the objective was to examine thermal stability, an upper limit of $93^{\circ} \mathrm{C}$ was chosen for this study. At this conditioning temperature, reductions in performance are expected. This is in agreement with research by Cutlip et al. (2008), who found that conditioning feed at $93^{\circ} \mathrm{C}$ resulted in decreased feed intake. Loar and authors (2014) also found detrimental effects associated with conditioning feed over $90^{\circ} \mathrm{C}$.

There is not a universally-accepted recommendation for steam conditioning temperatures, and due to the variability of heat stability among commercially available products, it is important to establish appropriate conditioning temperatures for specific phytase products. The objective of the current study was to evaluate three commercial 6-phytase products within a phosphorus deficient corn and soybean meal based diet subjected to increasing steam conditioning temperature on broiler performance and tibia mineralization. 


\section{MATERIALS AND METHODS}

\section{Birds and Husbandry}

Nine hundred sixty Hubbard x Cobb 500 straight-run broilers were obtained on the day of hatch, weighed, and randomly distributed into 96 raised-wire pens. The lighting program followed 23L: 1D from d1 to 7, and 20L: 4D from d8 to 20. Feed and water were provided on an ad libitum basis. Brooding temperature was maintained to maximize bird comfort. Birds were cared for according to West Virginia University Animal Care and Use Committee Guidelines.

\section{Dietary Treatments and Feed Manufacture}

The treatments included a negative control (NC) diet containing $0.2 \%$ non-phytate phosphorus (nPP) via dicalcium phosphate (DCP), and NC diets with the addition of three different commercial phytase products. The three phytase products evaluated were a phytase enzyme sourced from a Buttiauxella phytase expressed in Trichoderma reesei (B Trich), an E.coli phytase expressed in Pichia pastoris (E Pichia), and an E. coli phytase expressed in Trichoderma reesei (E Trich). Each phytase product was included at $1000 \mathrm{FTU} / \mathrm{kg}$. One phytase unit (FTU) may be defined as the quantity of enzyme required to liberate $1 \mu$ mol of inorganic $\mathrm{P}$ per minute from an excess of $1.5 \mathrm{mM}$ sodium at $37^{\circ} \mathrm{C}$, with a $\mathrm{pH}$ of 5.5 (International Union of Biochemistry, 1979). All four different diet formulations were conditioned at 82,88 , and $93^{\circ} \mathrm{C}$ and subsequently pelleted.

Feed manufacture was conducted at the West Virginia University pilot feed mill. Prior to diet formulation, samples of each enzyme were sent to two different labs for determination of phytase level. Upon analysis, the lower value reported for each enzyme (B Trich= $2080 \mathrm{FTU} / \mathrm{g}$, $\mathrm{E}$ Pichia $=4680 \mathrm{FTU} / \mathrm{g}, \mathrm{E}$ Trich $=5300 \mathrm{FTU} / \mathrm{g}$ ) was used in order to calculate a $1000 \mathrm{FTU} / \mathrm{kg}$ 
enzyme activity inclusion. Additional samples were analyzed for phytase activity following feed manufacture to determine how feed manufacture affected phytase levels.

Washed builders sand was used to standardize volume among the different phytase product inclusions to a $0.1 \%$ total inclusion (Table 1). The phytase product, sand, and $5 \mathrm{lbs}$. of ground corn were mixed for ten minutes in a 4.73-liter Hobart mixer [14] prior to final treatment batching and mixing. Each dietary treatment was mixed for ten minutes in a 1-ton vertical screw Easy Automation Inc. mixer [15]. This mix time was chosen because it has been shown to produce a homogenized diet, meaning it achieves a nutrient coefficient of variation of less than $10 \%$ [16]. Diets were steam conditioned using a short-term (10 s) conditioner and extruded through a $4.7 \times 38 \mathrm{~mm}$ pellet die driven by a 40-horsepower California Pellet Mill [17]. To ensure conditioning temperatures were met, hot pellet temperature was monitored for each treatment. Diets were then reduced to a small particle size via the roller mill to eliminate any variations in feed form. Finished feed was placed in open bags in a dry room containing a dehumidifier to ensure diets were of similar moisture (12\%).

Multiple samples of each treatment were collected and pooled for analysis of crude protein (Kjeldahl analysis), total calcium (AOAC method 927.02), total phosphorus (AOAC method 964.06), phytic acid (AOAC method 986.1) and phytase (AOAC method 2000.12). Pellet durability was determined 24 hours post-pelleting using the New Holmen Pellet Tester (NHPT) [18] (Table 2). Particle size and particle size standard deviation were determined using a $100 \mathrm{~g}$ representative sample passed through a RO-TAP RX-29 for a 10-minute processing period [19]. 


\section{Broiler Performance and Bone Mineralization}

Feed intake, live weight gain (LWG), mortality corrected feed conversion ratio (FCR), and mortality were calculated for the 20 -d growth period. On d 20, all birds were euthanized by cervical dislocation. Right tibiae were excised and used to determine ash weight and percentage. Tibiae were dried for $24 \mathrm{~h}$ at $105^{\circ} \mathrm{C}$. Fat was removed via extraction with petroleum ether in a soxhlet apparatus over a $16 \mathrm{~h}$ period. Bones were weighed and then ashed at $600^{\circ} \mathrm{C}$ for $18 \mathrm{~h}$. Ash weight was recorded for determination of ash percent and ash weight per chick.

\section{Statistical Analysis}

Bird performance and tibia measures were analyzed using the PROC GLM procedure of Statistical Analysis System (SAS) [20]. Variables were analyzed in a 4 x 3 factorial arrangement with the main effects of enzyme (No, B Trich, E Pichia, E Trich) and conditioning temperature $\left(82,88,93^{\circ} \mathrm{C}\right)$ within a randomized complete block design. The experimental unit was a pen of ten broilers. Significance was established at $\alpha=0.05$. Fisher's LSD multiple comparison test was used to separate means when interactions were significant. 


\section{RESULTS AND DISCUSSION}

Each diet formed one master batch that was then split and steam conditioned at the appropriate temperature. Increasing conditioning temperature resulted in decreased analyzed phytase values (Table 3). E Trich was the most thermally stable enzyme, followed by E Pichia. B Trich was the least stable enzyme used, providing insufficient levels of phytase when conditioned at 88 and $93^{\circ} \mathrm{C}$.

Broiler performance is presented in Table 4. The main effect product was significant for FI, LWG, and FCR. Broilers fed E Trich had the highest feed intake and LWG $(\mathrm{P}=0.0001)$. Boilers fed diets without phytase had the lowest FI and LWG, while broilers fed B Trich and E Pichia were intermediate in FI and LWG. Broilers fed B Trich and E Pichia had lower FCR $(\mathrm{P}=0.0321)$ when compared to broilers fed diets without phytase. Broilers fed $\mathrm{E}$ Trich were not distinguishable from other treatments in terms of FCR. The main effect conditioning temperature was significant for FI, and LWG. Increasing conditioning temperature sequentially decreased both FI and LWG $(\mathrm{P}=0.0001)$. Cutlip et al. (2008) also found that feeding pellets produced by high conditioning temperatures $\left(93.3^{\circ} \mathrm{C}\right)$ decreases broiler feed intake. However, that study also stated that increasing conditioning temperatures decreases feed conversion ratio. It is important to remember that diets in the current study were ground via a roller mill back to fines in order to observe the effect that increasing steam conditioning temperatures has on phytase activity rather than pellet quality. Increasing steam conditioning temperatures is known to increase pellet quality (Thomas and van der Poel, 1996; Table 2), and increased pellet quality may have effected bird performance and tibia mineralization differently. 
Phytase enzyme and conditioning temperature interacted to affect mortality. Broiler chicks provided the $\mathrm{NC}$ diet steam conditioned at $93^{\circ} \mathrm{C}$ had higher mortality than any other treatment. Steam conditioning at high temperatures has the ability to denature enzymes as well as other dietary protein, which would result in a smaller bird that would not be able to consume as much feed, and the nutrient deficiency may result in death. This theory is supported by Loar and others (2014), who found that increasing conditioning temperatures decreases the digestibility and bioavailability of nutrients. The main effects enzyme and conditioning temperature interacted to affect tibia ash percent $(\mathrm{P}=0.0016)$ and tibia ash $\mathrm{mg} / \mathrm{chick}(\mathrm{P}=0.0001)$. E Trich resulted in higher tibia measures compared to the other treatments. All enzymes resulted in decreased tibia measures with increased temperature, however the decrease was most drastic when feed was conditioned at $93^{\circ} \mathrm{C}$. This negative affect was not observed with broilers fed the NC. The decreased performance and tibia mineralization when exogenous phytase is included was likely associated with the denaturation of the enzyme as conditioning temperatures increase (Jongbloed and Kemme, 1999).

\section{CONCLUSIONS}

1) Commercial enzyme products demonstrated differences in supporting the phosphorus requirement in broilers.

2) Increasing conditioning temperatures had a detrimental effect on broiler performance and tibia mineralization. The increased conditioning temperatures may have decreased nutrient availability, denatured phytase products, or both of these events may have influenced the results. 


\section{REFERENCES AND NOTES}

1. Eeckhout, W., and M. De Paepe. 1994. Total phosphorus, phytate-phosphorus, and phytase activity in plant feedstuffs. Anim. Feed Sci. Technol. 47:19-29.

2. Harland, B.F., and D. Oberleas. 1999. Phytic acid complex in feed ingredients. Pages 6975 in Phytase in Animal Nutrition and Waste Management. M.B Coelho and E.T. Kornegay, ed. BASF Ref. Man., BASF Corp., Mount Olive, NJ.

3. Adeola, O. and J.S. Sands. 2003. Does supplemental dietary microbial phytase improve amino acid utilization? A perspective that it does not. J Anim. Sci. 81:78-85.

4. Bedford, M.R. and H. Schulze. 1998. Exogenous enzymes for pigs and poultry. Nut. Res. Rev. 11:91-114.

5. Ravindran, V., W.L. Bryden, and E.T. Kornegay. 1995. Phytates: Occurrence, bioavailability, and implications in poultry nutrition. Poult. Avian Biol. Rev. 6:125-143.

6. Greiner, R., N.G. Carlsson, and M. Larsson Alminger. 2000. Stereospecificity of myoinositol hexakisphosphate dephosphorylation by a phytate-degrading enzyme of Escherichia coli. Journal of Biotechnology 84:53-62.

7. Bedford, M.R. 2000. Exogenous enzymes in monogastric nutrition- Their current value and future benefits. Anim. Feed Sci. Technol. 86(1-2): 1-13.

8. Gurbuz Y., M. Cetin, and T. Sengul. 2009. Effect of phytase supplementation on performance, tibia ash, and serum $\mathrm{P}$ in broilers fed diets with different levels of phosphorus. J Appl. Anim. Res. 36:137-140.

9. Angel, R., N.M. Tamim, T.J. Applegate, A.S. Dhandu, and L.E. Ellestad. 2002. Phytic acid chemistry: Influence of phytin-phosphorus availability and phytase efficacy. J Appl. Poult. Res. 11:471-480.

10. Pieniazek, J., K.A. Smith, M.P. Williams, M.K. Manangi, M. Vazquez-Anon, A. Solbak, M. Miller, and J.T. Lee. 2016. Evaluation of increasing levels of a microbial phytase in phosphorus deficient broiler diets via live broiler performance, tibia bone ash, apparent metabolizable energy, and amino acid digestibility. Poult. Sci. 00:1-13

11. Loop, S.A., K.G.S. Lilly, L.K. Shires, C.K. Gehring, K.R. Beaman, M.E. Persia, and J.S. Moritz. 2012. The phytase analytical activity of pelleted diets may not adequately describe efficacy in the bird. J. Appl. Poult. Res. 21:492-501.

12. Loar II, R.E., K.G.S. Wamsley, A. Evans, J.S. Moritz, and A. Corzo. 2014. Effects of varying conditioning temperature and mixer-added fat on feed manufacturing efficiency, 28- to 42-day broiler performance, early skeletal effect, and true amino acid digestibility. J. Appl. Poult. Res. 23:444-455.

13. Jones, F. T., and K. E. Richardson. 2004. Salmonella in commercially manufactured feeds. Poult. Sci. 83:384- 391. 
14. Veldman, A., H. A. Vahl, G. J. Borggreve, and D. C. Fuller. 1995. A survey of the incidence of Salmonella species and Enterobacteriaceae in poultry feeds and feed components. Vet. Rec. 136:169-172.

15. International Union of Biochemistry. 1979. Enzyme Nomenclature: Recommendation of the Nomenclature Committee of the International Union of Biochemistry. Academic Press, New York, NY.

16. Hobart, Troy, OH.

17. MFP Vertical Mixer, Easy Automation Inc., Welcome, MN.

18. Reese, D.A., K.L. Foltz, J.S. Moritz. 2016. Effect of mixing and sampling method on pelleted feed nutrient analysis and diet formulation validation. J. Appl. Poult. Res. Accepted for publication.

19. Master Model Pellet Mill, California Pellet Mills Company, Crawfordsville, IN.

20. New Holmen Portable Pellet Durability Tester, Lignotech USA, INC., Rothschild, WI. $100 \mathrm{~g}$ of pellets were sifted through No. 5 American Society for Testing and Materials (ASTM) screen and placed in holding chamber, blown for $30 \mathrm{~s}$ by a jet of air, then weighed, giving a direct read of pellet durability. Fine is removed during the blowing process.

21. RO-Tap RX-29, W.S. Tyler, Mentor, OH.

22. SAS institute. 2013. The SAS system for Windows 2013. Release 9.3 SAS Inst. Inc., Cary, NC.

23. Cutlip, S.E., J.M. Hott, N.P. Buchanan, A.L. Rack, J.D. Latshaw, and J.S. Moritz. 2008. The effect of steam conditioning practices on pellet quality and growing broiler nutritional value. J. Appl. Poult. Res. 17:249-261.

24. Thomas, M., and A.F.B. van der Poel. 1996. Physical quality of pelleted animal feed. 1. Criteria for pellet quality. Anim. Feed Sci. Technol. 61:89-112.

25. Jongbloed, A.W., and P.A. Kemme. 1990. Effect of pelleting mixed feeds on phytase activity and the apparent absorbability of phosphorus and calcium in pigs. Anim. Feed Sci. Technol. 28:233-242. 
Table 1. Diet formulation and calculated nutrient values.

\begin{tabular}{|c|c|}
\hline Ingredient & $(\%)$ \\
\hline Corn & 55.45 \\
\hline Soybean meal $(48 \%)$ & 37.97 \\
\hline Soybean oil & 3.02 \\
\hline Limestone & 1.68 \\
\hline DL-Methionine & 0.48 \\
\hline Dicalcium phosphate & 0.37 \\
\hline Salt & 0.29 \\
\hline Vitamin mineral premix ${ }^{1}$ & 0.25 \\
\hline Sodium Bicarbonate & 0.15 \\
\hline Lysine & 0.12 \\
\hline Threonine & 0.12 \\
\hline Sand/Phytase $^{2}$ & 0.10 \\
\hline \multicolumn{2}{|c|}{ Calculated Nutrients } \\
\hline ME (kcal/kg) & 1,361 \\
\hline Crude Protein (\%) & 22.27 \\
\hline Digestible Lysine (\%) & 1.20 \\
\hline Digestible Methionine & 0.54 \\
\hline Digestible Methionine+ Cystine & 1.15 \\
\hline Digestible Threonine (\%) & 0.84 \\
\hline Digestible Arginine (\%) & 1.39 \\
\hline Digestible Tryptophan (\%) & 0.24 \\
\hline Calcium (\%) & 0.80 \\
\hline Available Phosphorus (\%) & 0.20 \\
\hline Sodium (\%) & 0.17 \\
\hline
\end{tabular}

${ }^{1}$ Supplied per kg of diet: manganese, $0.02 \%$; zinc $0.02 \%$; iron, $0.01 \%$; copper, $0.0025 \%$; iodine, $0.0003 \%$; selenium, $0.00003 \%$; folic acid, 0.69mg; choline, 386mg' riboflavin, 6.61 mg; biotin, 0.03mg; vitamin B6, 1.38mg; niacin, 27.56mg; pantothenic acid, 6.61mg; thiamine, 2.20mg; manadione, 0.83mg; vitamin B12,0.01mg; vitamin E, $16.53 \mathrm{IU}$; vitamin $\mathrm{D}_{3}, 2133$ ICU; vitamin A, 7716 IU.

${ }^{2} \mathrm{NC}=1.4 \mathrm{lbs}(100 \%)$ sand, B Trich $=0.73 \mathrm{lbs}(52 \%)$ sand and $0.67 \mathrm{lbs}(48 \%)$ phytase, E Pichia $=1.10 \mathrm{lbs}(79 \%)$ sand and 0.30 lbs $(21 \%)$ phytase, E Trich $=1.14 \mathrm{lbs}(81 \%)$ sand and $0.26 \mathrm{lbs}(19 \%)$ phytase. 
Table 2: Descriptive feed manufacture data of dietary treatments steam conditioned in a $0.31 \times 1.3 \mathrm{~m}$ conditioner for $10 \mathrm{~s}$ and extruded through a $4.7 \times 38 \mathrm{~mm}$ pellet die.

\begin{tabular}{|c|c|c|c|c|c|c|c|}
\hline Enzyme & $\begin{array}{c}\text { Conditioning } \\
\text { Temperature } \\
\left({ }^{\circ} \mathrm{C}\right)\end{array}$ & $\begin{array}{l}\text { Formulated } \\
\text { Available P } \\
\text { and Total Ca }\end{array}$ & $\begin{array}{c}\text { Hot Pellet } \\
\text { Temperature } \\
\left(^{\circ} \mathrm{C}\right)\end{array}$ & $\begin{array}{l}\text { Average } \\
\text { Pellet Mill } \\
\text { Motor } \\
\text { Amperage }\end{array}$ & $\begin{array}{l}\text { Production } \\
\text { Rate } \\
\text { (Tonne/hr) }\end{array}$ & $\begin{array}{c}\text { Pellet } \\
\text { Survivability } \\
\text { due to NHPT² } \\
\text { (\%) }\end{array}$ & $\begin{array}{c}\text { Crumble } \\
\text { Particle } \\
\operatorname{Size}^{3}(\mu \mathrm{m})\end{array}$ \\
\hline No & 82 & 0.20 and 0.80 & 85 & 19.55 & 0.814 & 67.82 & 1061.68 \\
\hline No & 88 & 0.20 and 0.80 & 89 & 19.85 & 0.807 & 83.79 & 1062.66 \\
\hline No & 93 & 0.20 and 0.80 & 96 & 20.50 & 0.806 & 93.78 & 1001.29 \\
\hline B Trich & 82 & 0.20 and 0.80 & 85 & 19.95 & 0.811 & 74.91 & 986.15 \\
\hline B Trich & 88 & 0.20 and 0.80 & 89 & 19.85 & 0.838 & 83.76 & 1036.46 \\
\hline B Trich & 93 & 0.20 and 0.80 & 94 & 21.40 & 0.835 & 91.97 & 991.21 \\
\hline E Pichia & 82 & 0.20 and 0.80 & 84 & 20.10 & 0.831 & 73.75 & 1036.52 \\
\hline E Pichia & 88 & 0.20 and 0.80 & 90 & 19.85 & 0.817 & 81.80 & 1084.57 \\
\hline E Pichia & 93 & 0.20 and 0.80 & 96 & 21.90 & 0.866 & 92.84 & 1007.77 \\
\hline E Trich & 82 & 0.20 and 0.80 & 86 & 19.75 & 0.844 & 71.87 & 969.80 \\
\hline E Trich & 88 & 0.20 and 0.80 & 89 & 19.55 & 0.853 & 80.09 & 1045.37 \\
\hline E Trich & 93 & 0.20 and 0.80 & 95 & 20.85 & 0.880 & 91.65 & 1006.39 \\
\hline & \multicolumn{7}{|c|}{$\begin{array}{l}{ }^{1} \text { Hot pellet temperature was determined on pellets directly following extrusion from the die. Pellets were collected into an } \\
\text { insulated container and temperature was measured using a thermocouple thermometer and an } 80 \mathrm{PK}-24 \text { temperature probe. } \\
{ }^{2} \text { Measurements of PDI were obtained using the New Holmen Pellet Tester, where } 100 \mathrm{~g} \text { pelleted samples are subjected to air } \\
\text { flow within a perforated chamber for } 30 \mathrm{~s} \text {. } \\
{ }^{3} \text { Particle size was determined with a Ro-Tap particle size analyzer model RX-29 Type } 110 \mathrm{~V} 60 \mathrm{H} 2 . \\
{ }^{4} \mathrm{~B} \text { Trich = Buttiauxella phytase expressed in Trichoderma reesei } \\
{ }^{5} \text { E Pichia = E.coli phytase expressed in Pichia pastoris } \\
{ }^{6} \text { E Trich = E. coli phytase expressed in Trichoderma reesei }\end{array}$} \\
\hline
\end{tabular}

Table 3. Analyzed nutrient content of diets provided to Hubbard x Cobb 500 broilers from 1-20 d of age.

\begin{tabular}{|c|c|c|c|c|}
\hline Treatment & Crude Protein (\%) & Calcium (\%) & $\begin{array}{c}\text { Non-Phytate } \\
\text { Phosphorus }(\%)^{1}\end{array}$ & $\begin{array}{l}\text { Phytase } \\
\text { (ftu/kg) }\end{array}$ \\
\hline $\mathrm{NC} @ 82^{\circ} \mathrm{C}$ & 23.40 & 0.987 & 0.172 & -- \\
\hline $\mathrm{NC} @ \mathbf{8 8}^{\circ} \mathrm{C}$ & 22.20 & 0.781 & 0.182 & -- \\
\hline $\mathbf{N C} @ 93^{\circ} \mathrm{C}$ & 21.85 & 0.761 & 0.185 & -- \\
\hline${ }^{2} \mathrm{~B}$ Trich @ $82^{\circ} \mathrm{C}$ & 22.00 & 0.885 & 0.181 & 580 \\
\hline B Trich @ $88^{\circ} \mathrm{C}$ & 21.92 & 0.805 & 0.184 & 200 \\
\hline B Trich @ 93 ${ }^{\circ} \mathrm{C}$ & 21.40 & 0.955 & 0.179 & $<70$ \\
\hline${ }^{3}$ E Pichia @ 82 ${ }^{\circ} \mathrm{C}$ & 21.39 & 0.832 & 0.179 & 880 \\
\hline E Pichia @ 88 C & 22.20 & 0.845 & 0.178 & 560 \\
\hline E Pichia @ $93^{\circ} \mathrm{C}$ & 21.73 & 0.894 & 0.184 & 140 \\
\hline${ }^{4} \mathbf{E}$ Trich @ 82 ${ }^{\circ} \mathrm{C}$ & 22.27 & 0.794 & 0.178 & 1100 \\
\hline E Trich @ $88^{\circ} \mathrm{C}$ & 22.17 & 0.843 & 0.184 & 1400 \\
\hline E Trich @ 93 ${ }^{\circ} \mathrm{C}$ & 21.72 & 0.871 & 0.186 & 250 \\
\hline
\end{tabular}

${ }^{1} \mathrm{nPP}=$ Total Phosphorus- (phytic acid $\mathrm{x} 0.282$ )

R. Angel et al. 2002

${ }^{2} \mathrm{~B}$ Trich $=$ Buttiauxella phytase expressed in Trichoderma reese $i$

${ }^{3}$ E Pichia $=$ E.coli phytase expressed in Pichia pastoris

${ }^{4} \mathrm{E}$ Trich $=$ E. coli phytase expressed in Trichoderma reesei 
Table 4. Statistical comparison of all dietary treatments as well as the factorial arrangement of treatments on $20 \mathrm{~d}$ Hubbard x Cobb straight-run broiler performance.

\begin{tabular}{|c|c|c|c|c|c|c|c|c|}
\hline Enzyme & $\begin{array}{l}\text { Conditioning } \\
\text { Temp. }\left({ }^{\circ} \mathbf{C}\right)\end{array}$ & $\begin{array}{c}\text { Starting } \\
\text { Pen Weight } \\
\quad(\mathrm{kg})\end{array}$ & $\begin{array}{l}\text { Feed Intake/ } \\
\text { bird (kg) }\end{array}$ & $\begin{array}{l}\text { Live Weight } \\
\text { Gain / bird } \\
\quad \text { (kg) }\end{array}$ & $\begin{array}{c}\text { FCR }^{1} \\
(\mathrm{~kg} / \mathrm{kg})\end{array}$ & $\begin{array}{c}\text { Mortality } \\
(\%)\end{array}$ & $\begin{array}{c}\text { Tibia Ash } \\
(\%)\end{array}$ & $\begin{array}{r}\text { Tibia Ash } \\
\text { (mg/chick) }\end{array}$ \\
\hline No & 82 & 0.436 & $0.686^{\mathrm{e}}$ & $0.597^{c}$ & 1.149 & $1.250^{\mathrm{bc}}$ & $42.624^{\mathrm{cd}}$ & $420.38^{\mathrm{gh}}$ \\
\hline No & 88 & 0.434 & $0.663^{\text {ef }}$ & $0.554^{\mathrm{d}}$ & 1.156 & $6.250^{\mathrm{bc}}$ & $42.138^{\mathrm{de}}$ & $378.76^{\mathrm{gh}}$ \\
\hline No & 93 & 0.437 & $0.562^{\mathrm{h}}$ & $0.471^{\mathrm{f}}$ & 1.122 & $15.000^{\mathrm{a}}$ & $40.838^{\mathrm{ef}}$ & $329.85^{\mathrm{i}}$ \\
\hline B Trich ${ }^{2}$ & 82 & 0.437 & $0.749^{\mathrm{abc}}$ & $0.682^{\mathrm{a}}$ & 1.094 & $1.250^{\mathrm{bc}}$ & $47.311^{\mathrm{a}}$ & $672.83^{\mathrm{ab}}$ \\
\hline B Trich & 88 & 0.434 & $0.708^{\text {cde }}$ & $0.641^{\mathrm{b}}$ & 1.103 & $3.750^{\mathrm{bc}}$ & $44.709^{b}$ & $517.77^{\mathrm{cd}}$ \\
\hline B Trich & 93 & 0.434 & $0.583^{\text {gh }}$ & $0.523^{\mathrm{e}}$ & 1.103 & $3.750^{\mathrm{bc}}$ & $39.587^{\mathrm{f}}$ & $375.24^{\mathrm{h}}$ \\
\hline E Pichia $^{3}$ & 82 & 0.434 & $0.744^{\mathrm{bcd}}$ & $0.643^{\mathrm{b}}$ & 1.107 & $7.500^{\mathrm{b}}$ & $44.729^{b}$ & $527.11^{\mathrm{c}}$ \\
\hline E Pichia & 88 & 0.435 & $0.689^{\mathrm{e}}$ & $0.615^{b c}$ & 1.119 & $0^{c}$ & $43.963^{\mathrm{bc}}$ & $484.20^{\mathrm{de}}$ \\
\hline E Pichia & 93 & 0.435 & $0.623^{\mathrm{fg}}$ & $0.543^{\mathrm{de}}$ & 1.110 & $6.250^{\mathrm{bc}}$ & $40.208^{f}$ & $356.32^{\mathrm{hi}}$ \\
\hline E Trich ${ }^{4}$ & 82 & 0.437 & $0.799^{\mathrm{a}}$ & $0.705^{\mathrm{a}}$ & 1.134 & $0^{c}$ & $47.571^{\mathrm{a}}$ & $706.45^{\mathrm{a}}$ \\
\hline E Trich & 88 & 0.438 & $0.775^{\mathrm{ab}}$ & $0.680^{\mathrm{a}}$ & 1.137 & $1.250^{\mathrm{bc}}$ & $47.058^{\mathrm{a}}$ & $646.65^{b}$ \\
\hline E Trich & 93 & 0.434 & $0.695^{\mathrm{de}}$ & $0.611^{\mathrm{c}}$ & 1.110 & $7.500^{\mathrm{b}}$ & $43.315^{\mathrm{bcd}}$ & $461.75^{\text {ef }}$ \\
\hline \multicolumn{2}{|c|}{ ANOVA P-value } & 0.0723 & 0.0001 & 0.0001 & 0.3346 & 0.0004 & 0.0001 & 0.0001 \\
\hline \multicolumn{2}{|c|}{ Fisher's LSD } & 0.0031 & 0.0514 & 0.0294 & 0.0511 & -- & 1.765 & 41.839 \\
\hline \multicolumn{2}{|c|}{ SEM $^{5}$} & 0.0011 & 0.0183 & 0.0104 & 0.0182 & 2.2899 & 0.6268 & 14.857 \\
\hline \multicolumn{9}{|c|}{ Marginal Means- Enzyme } \\
\hline \multicolumn{2}{|c|}{ B Trich } & 0.435 & $0.680^{\mathrm{b}}$ & $0.615^{\mathrm{b}}$ & $1.100^{\mathrm{b}}$ & 2.917 & 43.869 & 521.95 \\
\hline \multicolumn{2}{|c|}{ E Pichia } & 0.435 & $0.685^{\mathrm{b}}$ & $0.600^{\mathrm{b}}$ & $1.112^{\mathrm{b}}$ & 4.583 & 42.967 & 455.87 \\
\hline \multicolumn{2}{|c|}{ E Trich } & 0.436 & $0.756^{\mathrm{a}}$ & $0.665^{\mathrm{a}}$ & $1.127^{\mathrm{ab}}$ & 2.917 & 45.981 & 604.95 \\
\hline \multicolumn{2}{|c|}{ None } & 0.436 & $0.637^{c}$ & $0.540^{c}$ & $1.142^{\mathrm{a}}$ & 7.500 & 41.866 & 376.33 \\
\hline \multicolumn{2}{|c|}{ SEM } & 0.0006 & 0.0107 & 0.0063 & 0.0104 & 1.3200 & 0.3657 & 9.4366 \\
\hline \multicolumn{9}{|c|}{ Marginal Means- Conditioning Temperature ${ }^{\circ} \mathrm{C}$} \\
\hline & $82^{\circ}$ & 0.436 & $0.745^{\mathrm{a}}$ & $0.657^{\mathrm{a}}$ & 1.121 & $2.500^{\mathrm{b}}$ & 45.559 & 581.69 \\
\hline & $\mathbf{8 8}^{\circ}$ & 0.435 & $0.709^{\mathrm{b}}$ & $0.622^{\mathrm{b}}$ & 1.129 & $2.813^{\mathrm{b}}$ & 44.467 & 506.85 \\
\hline & $\mathbf{9 3}^{\circ}$ & 0.435 & $0.616^{\mathrm{c}}$ & $0.537^{\mathrm{c}}$ & 1.111 & $8.125^{\mathrm{a}}$ & 40.989 & 380.80 \\
\hline & SEM & 0.0006 & 0.0092 & 0.0054 & 0.0090 & 1.1431 & 0.3167 & 8.1724 \\
\hline \multicolumn{9}{|c|}{ Probability Values for Main Effects and the Interaction } \\
\hline & nzyme & 0.2584 & 0.0001 & 0.0001 & $\mathbf{0 . 0 3 2 1}$ & 0.0520 & 0.0001 & 0.0001 \\
\hline Conditioni & g Temperature & 0.4132 & 0.0001 & 0.0001 & 0.400 & 0.0009 & 0.0001 & 0.0001 \\
\hline $\begin{array}{r}\text { Enzyme } \\
\text { Ten }\end{array}$ & $\begin{array}{l}\text { Conditioning } \\
\text { perature }\end{array}$ & 0.0672 & 0.5825 & 0.0707 & 0.9356 & 0.0179 & 0.0016 & 0.0001 \\
\hline \multicolumn{9}{|c|}{$\begin{array}{l}{ }^{2} \mathrm{~B} \text { Trich }=\text { Buttiauxella } \text { phytase expressed in Trichoderma reesei } \\
{ }^{3} \mathrm{E} \text { Pichia = E.coli phytase expressed in Pichia pastoris } \\
{ }^{4} \mathrm{E} \text { Trich = E. coli phytase expressed in Trichoderma reesei } \\
{ }^{5} \mathrm{SEM}=\text { Standard Error of the Mean }\end{array}$} \\
\hline
\end{tabular}

